\title{
PHILOSOPHY AND CULTURE: THINKING ABOUT GLOBAL CRISES
}

\author{
John Ozolins \\ Australian Catholic University Limited115 Victoria Pde, \\ Fitzroy Victoria 3065Australia
}

\begin{abstract}
The world is beset by what seem to be an interminable set of problems. Many of these, increasingly, are transnational, which is to say, that they transcend the borders of individual nations. Issues such as climate change and apparent global warming are fiercely debated, with many arguing that without a change in the way in which human beings abuse the environment, we are all doomed. The crisis in 2011 surrounding the destruction of the nuclear reactor in Fukushima, Japan as a result of the devastation wrought by the massive earthquake and tsunami points to human powerlessness in the face of the forces of nature. It also points to the need to show respect for those same forces. Other crises, such as the global financial crisis in 2008, also have had a profound impact on human lives. While it is difficult to quantify, the global financial crisis has undoubtedly been responsible for many deaths also, as aid money decreases and projects which may have helped solve housing shortages, provided sanitation and clean water are unable to proceed. There is a need to reconfigure capitalism so that it serves the common good, rather than the self indulgent needs of venal speculators. Glaring inequalities in the distribution of the common wealth of countries are just as evil in the United States, China, India, Australia and the United Kingdom, to name a few of the G20 nations, as they are anywhere else. The waves of protest throughout the Middle East which saw the ousting of the Libyan dictator, Gaddafi and the Egyptian president Mubarak, should not be seen as simply a sign of the inherent instability in those countries, but as a sign that oppressive policies wherever they are met will eventually result in the overthrow of corrupt regimes. The situation in Syria is, of course, particularly parlous and points to the need for stronger international law. This paper argues that philosophy has a serious role to play in thinking about global issues and, using the example of global ethics, shows how it is central in the explication of the values that underpin proposed solutions to global problems. Though cultures are different, it is proposed, recent history shows that human beings share common values and purpose.
\end{abstract}

Key words: Globalisation, Global Crises, Global Ethics, Human Rights.

\section{PART II}

\section{The Role of Philosophy and Culture}

At first glance, it does not seem that philosophy has much relevance in the various global problems that we have outlined. These seem to require political and economic solutions that have little to do with philosophy. It is certainly true that some of the most important problems to be considered require politicians, corporations, scientists and public servants to work together to solve the myriad global crises facing the world.

(C) John Ozolins, 2018 
Crises such as that occurring in Syria require extensive political skills and negotiating ability to effect a solution, the global financial problems require economists and financial advisors to find ways of stabilising markets, scientists are needed to predict the possible consequences of changing climate and public servants to implement the policies of governments in relation to all these crises. Philosophy and philosophers do not seem to have any significant part to play.

To conclude that philosophy and philosophers have little or no role to play in the tackling of global crises would be a mistake. It is a mistake because none of the major problems that constitute global crises can be addressed without some analysis of them and without some evaluation of the beliefs and values which are foundational to the assessment of the means to be used in tackling the problem. For example, in considering the civil war in Syria, there is the question of the obligations of neighbouring states to intervene to save innocent lives. This then requires, for instance, consideration of the limits of sovereignty and the application of just war theory, which are both philosophical questions. In considering issues related to the financial crises besetting the world, questions about the aims of business arise and whether profit should be the sole motivation for economic activity. This too, is a philosophical question about the kinds of beliefs and values that underpin the principles on which a particular conception of society is founded. Discussion of what ought to be done in relation to climate change and other environmental matters does not take place in a vacuum, but within a particular value and belief system. Thus, those that do not believe that there is any significant climate change reject any action to alter the use of fossil fuels, while those who do, make every effort to use alternative energy sources. These differences are not based on scientific evidence, but on particular belief and value systems. Philosophers have a role to play in philosophical questions about the conceptual frameworks in which questions about climate change are considered. For example, what is meant by climate change, as it is apparent that climate changes on a daily basis. Sharpening such conceptions is very much a task of philosophy. Finally, it is also clear that the policies devised by governments are also subject to political beliefs and values and so involve philosophical views. A government inclined towards libertarianism, for example, will devise policies that interfere minimally in the lives of its citizens by outsourcing as many functions as it can to the private sector. A more communitarian government will see its role differently and take responsibility for providing services itself. The roles of public servants will correspondingly be different. Philosophy and philosophers, whether this recognised formally or not, play a significant role in the clarification of each of the philosophical position that is adopted.

Neither are the various global crises that we have considered disconnected from culture, since not only does culture influence the way particular issues are viewed, but also how they are addressed. Culture is not disconnected from philosophy in this respect, since broad divisions can be recognised between different philosophical approaches that arise in different cultures. This is not altogether surprising, since we would expect that 
different environments and experiences will create different outlooks on the world. A maritime culture, for example, will have different ways of viewing the world to a landlocked community high in a mountain range and remote from the sea. A desert community will have a very different attitude to water, for instance, than one in which flooding is a regular occurrence. Experiences of diverse kinds will affect the way in which different crises are viewed, since these will be reflected in the culture of the particular people. Philosophers are not immune to cultural influences, since their philosophising also takes place within a framework of their own experiences and those aspects of culture that they have absorbed, perhaps unconsciously.

Recognising the culturally bound nature of philosophical thought, if we want to have understand, say, Chinese culture, in any profound way it will not be particularly useful if the only standpoint from which we seek to appreciate it is from that of our own culture. This is the important lesson that both Nagel and Mac Intyre seek to teach us in their different ways. Nagel in discussing objectivity and subjectivity, observes that there is no view from nowhere, that our assessments of various problems and issues are never divorced from our own cultural backgrounds and our philosophising is never from a God's eye point of view, but always immersed in a particular time and culture. If we want to obtain an objective view, we need to step back from our own prejudices and preconceptions, but Nagel notes that in ethics it is never possible to eliminate the subjective. ${ }^{1}$ Mac Intyre also reminds us that our thinking always takes place within a particular tradition and this will be informed by our cultural practices. ${ }^{2}$

To illustrate the differences, we need to consider how culture affects the way in which philosophy is practised. This is not always easy, as philosophy crosses many cultural boundaries, yet it is possible to see the effects of culture. Because culture includes language, philosophical perspectives will be affected by the language of discourse. Quine reminds us of the difficulty of translating a discourse carried on in one language into another, arguing for the inscrutability of reference and indeterminacy of translation. ${ }^{3}$ Gadamer also insists that the achievement of thought takes place within something which is firm, that is, morals, law and religion, which is to say within a cultural tradition which acts as the bedrock for thought. ${ }^{4}$ Wittgenstein notes that how the world is viewed will to a large extent be determined by the way in which it is described by language, since it expresses a form of life. ${ }^{5}$ It can be concluded that paying attention to the way in which ideas are expressed in language will provide a means of illuminating how different philosophical concepts are understood.

${ }^{1}$ Nagel, T. (1989) The View from Nowhere, Oxford: Oxford University Press, 8-9

${ }^{2}$ MacIntyre, A. (2007) After Virtue, $3^{\text {rd }}$ Edition, Notre Dame, Ind.: Notre Dame University Press

${ }^{3}$ Quine, W.V.O. (1960) Word and Object, Cambridge, Mass.: The M.I.T. Press

${ }^{4}$ See Gadamer, H-G. (1989) Truth and Method, $2^{\text {nd }}$ Revised Edition, tr. rev. J. Weinsheimer and D.G. Marshall, London: Sheed and Ward, 235-236

${ }^{5}$ Wittgenstein, L. (1953) Philosophical Investigations, tr. G.E.M. Anscombe, Oxford: Basil Blackwell, para. 19. 
Given the culturally affected nature of philosophy, however, does not mean that there are not commonalities to be found between different ways of thinking nor that there may not be universal beliefs and values. These, however, will be expressed in different ways and will almost certainly begin from different starting points. For some philosophers, irrespective of their cultural background, and here we can point to Aquinas and Mengzi, as representatives of very different cultures, eras and traditions, an understanding of virtue, for example, will depend on an understanding of human nature and what is thought to be best for human beings. If there is a common human nature and there are good grounds for thinking there is, then though there will be different starting points for conceiving of virtue, what is considered to be good for human beings will essentially be the same. A study of both these thinkers, much beyond our scope here, will show some surprising agreement about what is good for human beings.

There will, however, be significant differences in the elaboration of the virtues and the underlying principles supporting each conception of the virtues will be quite different. Aquinas, for example, starts from an Aristotelian and Christian perspective, adding to the cardinal virtues of Aristotle the Christian virtues of faith, hope and charity. Mengzi begins with the idea that human nature is good and that the sprouts of the virtues have been given to human beings by Heaven. That both Aquinas and Mengzi arrive at the conclusion that what is good for human beings is the virtuous life is not that surprising, since both assume the essential goodness of human nature and that human fulfilment demands its continued development. The essential virtues are elaborated by each, however, divide up the overall notion of virtue or moral goodness in quite different ways. Setting aside the Christian virtues of faith, hope and charity, Aquinas's cardinal virtues are courage, temperance, justice and prudence, while Mengzi's are humaneness, rightness, propriety and practical wisdom. These have similarities to one another, but are different ways of thinking about virtue overall. Once these virtues are detailed, however, it is clear that the end of the cultivation of virtue for both is human fulfilment and this is union with God or Heaven. ${ }^{1}$

Though the end of the cultivation of moral virtue is moral goodness, the path to this endpoint is not necessarily the same for everyone and all cultures. The contours of what the good life consists of will essentially be the same, but possibly quite different in its realisation. In considering the prospect of a global ethics, we should be cautious, since if the argument we have been presenting is plausible, then the domain of the virtues will be carved differently and this will mean different approaches to how virtue is to be realised. Awareness of this is helpful in the consideration of what brings us together in thinking about the values that underpin approaches to global problems. Moreover, diversity of views about virtue and perspectives on values need not undermine the prospects of

${ }^{1}$ How God and Heaven are to be understood is another issue. It suffices to say here that what both agree about is that human fulfilment has a goal. 
agreements about common values and to that extent, can support a global ethics. What should be resisted, however, is the idea that there can be a global ethics that consists of the virtues understood in the same way.

\section{Global Ethics}

Normative ethical theories all purport to be universally applicable, so to speak of global ethics or globalised ethics seems to be quite redundant. Hans Kung, however, points out the intent of global ethics as being the acceptance of a certain minimum of common values, standards and basic attitudes. Kung says global ethics is: "a minimal basic consensus relating to binding values, irrevocable standards and moral attitudes, which can be affirmed by all religions despite their undeniable dogmatic or theological differences and should also be supported by non-believers."

More broadly, we can re-express Kung's definition of global ethics as a minimal basic consensus to values, irrevocable standards and moral attitudes, which can be affirmed by all cultures, despite their many differences. The difficulty, however, is whether the principles of global ethics to which everyone can assent would be robust enough to enable agreed ethical decisions to be made in a variety of areas, as all that is demanded is a minimal basic consensus. If the path to virtue, understood as human fulfilment, allows for different understandings of virtues, then it follows that there will be different perspectives on what the minimal consensus is about. The right to education, for example, even if it is affirmed by everyone, will not be understood by every nation and culture as demanding the same access to education. In some cultures, the idea that there should be universal access to tertiary education, for instance, is not considered as having the same level of importance as primary and secondary education. Moreover, given the seriousness of many global questions, minimal consensus will not be sufficient for agreement on how to proceed to tackle these issues. The lack of consensus on market regulation, for example, shows how unrealistic the demand for consensus is. In order to make any headway with global problems, several conditions need to be met. In general, amongst other things, there needs to be agreement: (i) about the nature of the problem itself; (ii) about its urgency; (iii) its priority amongst other problems; (iv) who is to take responsibility for tackling the problem; (v) how it is to be tackled; (vi) what resources are needed. Each of these conditions will involve value judgements and while some minimal consensus is helpful, recognition that a particular problem is a common global problem is the most important condition.

While it is unclear whether a sufficiently robust global ethics can be established, philosophy is crucial in providing the reflection that is necessary in thinking about the

${ }^{1}$ Hans Kung (2005) Global Ethic and Human Responsibilities Available online at http://www.scu.edu/ ethics/practicing/focusareas/global_ethics/laughlin-lectures/global-ethic-human-responsibility. html Accessed: 27/05/13 
values which underpin the different perspectives on global issues. Though science can be expected to provide empirical evidence for climate change, for example, it is philosophy which asks for clarification about what is meant by climate change and which establishes the independent rules of evidence that helps in the assessment of the evidence. In relation to its urgency, though it is also a political and economic question, it is also a philosophical question, since for a nation the extent to which it is able to address a question will also depend on other competing problems. The alleviation of poverty, for example, may demand acceptance of a higher level of pollution since the cost of cheap energy from coal is considered less than that from green energy. A country with fewer options in relation to energy may be forced to continue to use sources of energy that it knows are polluting. Philosophy provides the critical reflective resources to enable competing positions and competing values to be evaluated.

Another example that reinforces the importance of philosophy in providing the critical resources to evaluate competing positions is provided by the 2011 disaster in Fukushima, Japan. Aside from the terrible cost in human life, the catastrophe caused by the earthquake and tsunami to the nuclear power plant at Fukushima has resulted in some rethinking of the merits of generating electricity by nuclear power. The fear is no longer of world destruction by nuclear weapons, though some fear of this remains, but the possibility of a nuclear disaster which affects the global community. The escape of nuclear waste materials into groundwater not only affects the water, but all the life that depends on that water. Airborne radiation does not respect national boundaries either. Exposure to radiation may not have immediate effects, but there are considerable long term health risks. Science provides the data about levels of risk and the actions that need to be taken to limit these risks, but it will be philosophy that is required to evaluate these. A global ethics that remains at a general consensual level will not be enough, but a philosophical analysis that takes into account not only diverse normative ethical theories in its evaluation, but also the effects of culture, will provide a better basis for decision-making, as well as an understanding of the diverse contributions that are made to the making of those decisions.

Although there is a diversity of heterogeneous cultures and values, the global crises that we face threaten all human beings and hence it is not a matter of choice what are considered problems. Thus, the risks posed by the contamination of the atmosphere by nuclear waste from nuclear power plants are common problems, not simply Japanese ones that occurred as a result of the tsunami that was experienced. The idea of global ethics is premised on the view that there are common aspirations that human beings share and that there is a common good that all hope for. More importantly, human beings share a common human nature which is affected by the same kinds of physical events, such as nuclear radiation. There is no escaping the fact that human beings all need food, shelter, clean water to drink and clean air to breathe. A case can also be made for human beings sharing other kinds of needs, such as a need for peace of mind, need for friends, 
for freedom of expression and security. These commonalities, arguably, provide the reasons for thinking that though there are diverse perspectives on values and virtues, they converge on the same kind of good for human beings. ${ }^{1}$ It is self-evident, after all, that it is in no one's interest that airborne nuclear radiation should be allowed to circulate in the atmosphere. The need for understanding of diverse values and a sense of the common good in relation to common global problems is urgent and the movement towards elaborating a global ethics is a recognition of this.

\section{The Declaration of Human Rights}

As a document that recognises the urgency of consensual approaches to common human problems, the Declaration of Human Rights is a useful starting point, though it is largely a Western document. Despite this, although it is more than 60 years since the United Nations Declaration on Human Rights, it remains one of the most significant statements on the principles that should govern the ethical decision-making of all human beings, but, one might add, the leaders of nations, states and corporations who have the power to affect many lives. The U.N. Declaration is not without controversy and many of its principles remain to be implemented in various corners of the world. Nonetheless, it has guided the decision-making of the United Nations and the development of its aid programs throughout the world. It remains one of the few documents on which there is some common agreement. More recently, and significantly in the light of what we have been discussing, the rise of globalisation, the U.N. warns, has the potential to erode human rights even further.

The UN Statement on globalisation and economic, social and cultural rights notes the growth of globalisation and warns that market economies and the growth of international financial markets has the potential to influence national policies and affect the livelihoods of a great many people. We have already noted the effect of the GFC on the lives of many people. The statement in relation to human rights says:“...globalization risks downgrading the central place accorded to human rights by the United Nations Charter in general and the International Bill of Human Rights in particular. This is especially the case in relation to economic, social and cultural rights. Thus, for example, respect for the right to work and the right to just and favorable conditions of work is threatened where there is an excessive emphasis upon competitiveness to the detriment of respect for the labor rights contained in the Covenant. The right to form and join trade unions may be threatened by restrictions upon freedom of association, restrictions claimed to be "necessary" in a global economy, or by the effective exclusion of possibilities for collective bargaining, or by the closing off of the right to strike for various occupational and other groups. The right of everyone to social security might not be ensured by arrangements which rely entirely

${ }^{1}$ Not everyone agrees with this. Some philosophers, such as Richard Rorty, argue that there is no common human nature, though what exactly he means by this is not clearly explicated by him. See Rorty, R. (1989) Contingency, Irony and Solidarity, Cambridge: Cambridge University Press. 
upon private contributions and private schemes. Respect for the family and for the rights of mothers and children in an era of expanded global labor markets for certain individual occupations might require new and innovative policies rather than a mere laissez-faire approach. If not supplemented by necessary safeguards, the introduction of user fees, or cost recovery policies, when applied to basic health and educational services for the poor can easily result in significantly reduced access to services which are essential for the enjoyment of the rights recognized in the Covenant. An insistence upon higher and higher levels of payment for access to artistic, cultural and heritage-related activities risks undermining the right to participate in cultural life for a significant proportion of any community." 1

The continued growth of market economies around the world and the erosion of basic services is evident throughout the developed world. For example, though indicators in relation to employment in Western nations are mixed, with some boasting falling unemployment rates and rising wages, others have rising unemployment, especially among the young, and falling wages. In both situations, basic housing is becoming increasingly out of reach of average wage earners and obviously is not accessible to the unemployed. Health, welfare and education services are also becoming significantly out of reach of the poor. The middle class is also shrinking as a result of the redistribution of wealth to the very rich. The situation in developing world is substantially worse. The problems to which we have already alluded are the result of unregulated markets and a lack of consensus over the common good which should be ultimately the aim of human activity. We all have to live together on the one planet and what one person does affects others. Similarly, what one nation, one corporation or one entrepreneur does affects others.

Mass communication, travel and the growing realisation of the interconnectedness of all peoples at the global level has increased the need for human beings to find practical ways to work together to secure the future of the world. One way that has been proposed has been the design of a global ethic which will encapsulate those values on which all people can agree. The problems is that if there are fundamental differences about the nature of the common good this will prove to be difficult. The United Nations Declaration of Human Rights is a beacon which provides some optimism that, though there may be difficulties in gaining consensus on common values, respect for one another may enable creative solutions to emerge from a common desire to find practical solutions to global problems.

Philosophy has a crucial role to play in deliberations about the nature of the common good, about the understanding of values in different cultures and in explicating their foundations. Importantly, even as we seek common ground or a global ethics, based perhaps on the U.N. Declaration of Human Rights, cultural and language differences

${ }^{1}$ United Nations Committee on Economic, Social and Cultural Rights (1998) Statement on Globalization and Economic, Social and Cultural Rights, May , 1998, Geneva: Office of the United Nations Commissioner for Human Rights 
cannot be ignored, since different perspectives from diverse cultures can cast illumination on a particular problem. Global crises require not so much agreement about values, but about common aspirations and about what fulfils human beings. Global ethics, despite providing ethical principles that are unlikely to be ever fully agreed upon, does imply that there are common problems that a common approach might have help to resolve. Philosophy, because it seeks the truth, provides the resources for deliberations about global crises.

\section{REFERENCES:}

1. Aristotle (1976) The Politics, Harmondsworth: Penguin, Book I Chapter 9, [1258a].

2. A Year of Crises: UNHCR Global Trends 2011. At URL http://www.unher. org/4fd6f87f9.html Accessed: 20/5/2013.

3. Banks G., Ballard C. (eds.) (1997) The Ok Tedi Settlement: Issues, Outcomes and Implications, Pacific Policy Paper 27, Canberra: National Centre for Development Studies and Resource Management in Asia-Pacific, Research School for Pacific and Asian Studies, Australiana National University.

4. Boughton E. (2005) "The Bhopal Disaster and its Aftermath: A Review", Environmental Health: A Global Access Source, 4, 6.

5. Frynas J. (1998) "Political instability and business: focus on Shell in Nigeria", Third World Quarterly, 19, 3, 457-478.

6. Gadamer H-G. (1989) Truth and Method, $2^{\text {nd }}$ Revised Edition, tr. rev. J. Weinsheimer and D.G. Marshall, London: Sheed and Ward, 235-236.

7. Kristof N. (2017) Is this Genocide? New York Times,December $5^{\text {th }}$. At URL https:// www.nytimes.com/2017/12/15/opinion/sunday/genocide-myanmar-rohingyabangladesh.html Accessed 22/2/2018.

8. Kung H. (2005) Global Ethic and Human Responsibilities. At URL http://www.scu. edu/ethics/practicing/focusareas/global_ethics/laughlin-lectures/global-ethic-humanresponsibility.html Accessed: 27/05/13.

9. MacIntyre A. (2007) After Virtue, $3^{\text {rd }}$ Edition, Notre Dame, Ind.: Notre Dame University Press.

10. Nagel T. (1989) The View from Nowhere, Oxford: Oxford University Press, 8-9.

11. Ozolins J. (2009) "Human Beings as Resources: The Ethics of Buying and Selling Human Tissues and Organs", Ethics Education, 15, 1, 5-19.

12. Pettiford L., Harding D. (2003) Terrorism: The New World War, Slough: Arcturus; Freilich J., Guerette, R. (eds.) (2006) Culture, Conflict, Crime and Terrorism, Abingdon, Oxon.: Ashgate; Zimmerman, E. (2011) "Globalisation and Terrorism", European Journal of Political Economy, 27, S152-S161. 
13. Pincock S. Survival of the fishes. At URL http:/www.abc.net.au/science/articles/ 2010/09/09/3003951.htm Accessed: 2/4/2011.

14. Rorty R. (1989) Contingency, Irony and Solidarity, Cambridge: Cambridge University Press.

15. The Al-Jazeera Report (November 2017) on the humanitarian crisis. At URL http: // www.aljazeera.com/programmes/insidestory/2017/11/yemen-humanitarian-crisissolved-171116184 Accessed: 22/2/2018.

16. The newspaper article in The Guardian. At URL http://www.guardian.co.uk/world/2013/ may/01/scientists-concerned-h7n9-bird-flu-outbreak Accessed: 20/5/2013.

17. Twiss S. (2004) "History, Human Rights and Globalisation", Journal of Religious Ethics, 32, 1, 39-70.

18. Quine W. (1960) Word and Object, Cambridge, Mass.: The M.I.T. Press.

19. United Nations Committee on Economic, Social and Cultural Rights (1998) Statement on Globalization and Economic, Social and Cultural Rights, May, 1998, Geneva: Office of the United Nations Commissioner for Human Rights.

20. Wittgenstein L. (1953) Philosophical Investigations, tr. G.E.M. Anscombe, Oxford: Basil Blackwell, para. 19.

\title{
ФІЛОСОФІЯ І КУЛЬТУРА: МІРКУВАННЯ ПРО ГЛОБАЛЬНІ КРИЗИ
}

\author{
Джон Озолінс \\ Австралійський католищький університет, 115 Вікторія, \\ Фіцрой Вікторія 3065 Австралія
}

\begin{abstract}
Світ охоплений, здавалось би, нескінченними проблемами. Багато з них виходять на міждержавний рівень, тобто за межі окремих держав. Такі питання як зміна клімату та очевидне глобальне потепління, яро обговорюють; багато хто стверджує, що якщо люди не змінять свої підходи до природокористування, то всі ми приречені. Криза 2011 р., пов'язана 3 аварією на ядерному реакторі у префектурі Фукушіма, Японія, що сталася внаслідок руйнувань, спричинених сильним землетрусом і цунамі, вказує на людську безпорадність перед силами природи. Вона також вказує на потребу поважати ці сили. Інші кризи, такі як світова фінансова криза 2008 р., також мали наскрізний вплив на людські життя. Хоч це й складно підрахувати, та немає сумнівів, що світова фінансова криза також стала причиною смертей, адже кількість грошей на допомогу зменшилася, проекти, які могли б посприяти вирішенню проблеми з нестачею житла, покращенням санітарії та забезпеченням чистою водою, припинилися. Існує потреба перебудувати капіталізм, щоб він служив для загального блага, а не для егоїстичних потреб корисливих спекулянтів. Разюча нерівність у розподілі спільного багатства країн однаково жахлива, як в Сполучених Штатах, Китаї,
\end{abstract}


Індії, Австралії чи Об'єднаному Королівстві (а це лише декілька країн, що входять до Великої двадцятки), так і в усіх інших країнах. Хвилі протестів на Близькому Сході, що стали причиною вигнання лівійського диктатора Каддафі та єгипетського президента Мубарака, варто розглядати не лише як ознаку властивої цим країнам нестабільності, а i як ознаку того, що репресивна політика, де б вона не проводилася, в кінцевому результаті призводить до повалення корумпованого режиму. Звісно, ситуація в Сирії особливо складна й вказує на потребу в сильнішому міжнародному праві. В цій статті аргументовано, що філософія повинна відігравати важливу роль у міркуваннях про глобальні питання i, використовуючи приклад глобальної етики, показано, що вона відіграє центральну роль в експлікації цінностей, які є основою запропонованих вирішень глобальних проблем. Хоч культури - різні, новітня історія показує, що люди мають спільні цінності й призначення.

Ключові слова: глобалізація, глобальні кризи, глобальна етика, права людини 